\title{
Food of sand smelt, Atherina boyeri Risso, 1810 (Pisces: Atherinidae) in the estuary of the Mala Neretva River (middle-eastern Adriatic, Croatia)*
}

\author{
VLASTA BARTULOVIĆ ${ }^{1}$, DAVOR LUČIĆ ${ }^{2}$, ALEXIS CONIDES ${ }^{3}$, \\ BRANKO GLAMUZINA ${ }^{4}$, JAKOV DULČIĆ ${ }^{4}$, DUBRAVKA HAFNER ${ }^{5}$ \\ and MIRNA BATISTIĆ ${ }^{2}$ \\ ${ }^{1}$ Department of Aquaculture, University of Dubrovnik, Ćira Carića 4, 20000 Dubrovnik, Croatia. E-mail: vlasta@unidu.hr \\ ${ }^{2}$ Institute of Oceanography and Fisheries, Kneza Damjana Jude 12, Dubrovnik, Croatia. \\ ${ }^{3}$ Hellenic Centre for Marine Research, Agios Kosmas, Agios Kosmas, Hellinikon, 16604 Athens, Greece. \\ ${ }^{4}$ Institute of Oceanography and Fisheries, Split, Croatia. \\ ${ }^{5}$ Faculty of Education, University of Mostar, Mostar, Bosnia-Herzegovina.
}

\begin{abstract}
SUMMARY: The feeding habits of sand smelt, Atherina boyeri Risso, 1810 in the mouth of the Mala Neretva River were studied by examining the stomach contents of 1236 fishes collected from March 2001 to February 2002. Thirteen different food categories were identified. The greatest diversity was recorded in winter, especially in January, when 11 categories were present. The minimum (4) was in September, and was associated with the highest number of empty stomachs. Marine and estuarine species represented the bulk of the prey, while typically fresh-water species (Daphnia spp. and Cyclops spp.) were found only sporadically. Crustaceans were the most common prey and, of these, the most common were copepods (45\%), followed by gammarid amphipods (34\%), cladocerans (13\%), decapod larvae (12\%) and mysids (8\%). Insects represented $7 \%$. The percentage number of prey showed high seasonal variations. Copepods dominated in autumn and winter, cyclopoids in April, poecilostomatoids and harpacticoids in December, and calanoids in January and February. Decapod larvae dominated in March-May, and mysids in July-August. PCA and clustering analysis was performed on the prey data in order to reveal associations between prey items or seasonal similarities. The opportunistic mode of feeding of the species Atherina boyeri is also discussed.
\end{abstract}

Key words: sand smelt, food, Neretva River estuary, Croatia.

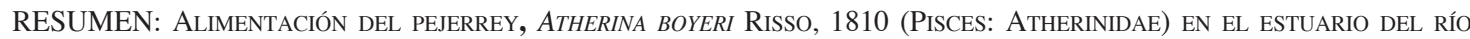
NeretVa (Adriatico MEDIO-ESTE, CROACIA). - Los hábitos alimenticios del pejerrey, Atherina boyeri Risso, 1810 en la boca del río Mala Neretva se estudiaron mediante el examen del contenido estomacal de 1236 peces recolectados desde marzo de 2001 a febrero de 2002. Se identificaron 13 categorías diferentes de alimento. La mayor diversidad se observó en invierno, especialmente en enero, en que estuvieron presentes 11 categorías.. El mínimo (4) se observó en septiembre, y se asoció al mayor número de estómagos vacíos. Las especies marinas y estuáricas representaron el principal grupo de presas, mientras que especies típicas de agua dulce (Daphnia spp. y Cyclops spp.) se encontraron sólo esporádicamente. Los crustáceos fueron las presas más comunes, siendo los copépodos los más frecuentes (45\%), seguido de los amfípodos gammaridos $(34 \%)$, cladóceros $(13 \%)$, larvas de decápodos $12 \%$, misidáceos $8 \%$, e insectos $7 \%$. El porcentaje de presas mostró una alta variación estacional. En general, los copépodos dominaron en otoño e invierno: los Cyclopoides fueron más numerosos en abril, los poecilostomátidos y harpacticoides en diciembre y los calanoides en enero y febrero. Las larvas de decápodo dominaron en marzo-mayo y los misidáceos en julio-agosto. Con los datos de presas se realizaron análisis multivariantes para revelar asociaciones entre presas o similaridades estacionales. En este trabajo se discute, también, el modelo de alimentación de tipo oportunista de la especie Atherina boyeri.

Palabras clave: pejerrey, alimentación, río Mala Neretva, Croacia.

*Received January 12, 2004. Accepted April 29, 2004. 


\section{INTRODUCTION}

The sand smelt, Atherina boyeri [Risso 1810], is common in the Mediterranean and its adjacent seas, and is also found in the northeast Atlantic, from the Azores to the northwest coast of Scotland. It is a small, short-lived, euryhaline (Quignard and Pras, 1986) fish that inhabits mainly coastal and estuarine waters and, more rarely, inland waters. The species has also been introduced into freshwater lakes and reservoirs for stock enhancement purposes (Economidis et al., 2000).

Sand smelt are opportunistic feeders. In typical coastal ecosystems they prey on zooplankton, while in lagoons and estuaries they feed on benthic organisms (Kiener and Spillman, 1969; Trabelsi et al., 1994). Some authors have found that sand smelt feed mainly on zooplankton and only secondarily on benthic organisms (Rosecchi and Crivelli, 1992), while others have found a preference for benthic prey (Scipiloti, 1998). Research based on the ratios of stable carbon and nitrogen isotopes also suggests a clear feeding preference for benthic organisms, mainly Isopoda and Mysidacea (Vizzini and Mazzola, 2002). Some of the differences in conclusions drawn from gut and isotope analyses may relate to differences in ingested versus assimilated food (Scipiloti, 1998; Vizzini and Mazzola, 2002). Other studies have identified changes in food selection related to seasons (Trabelsi et al., 1994; Scipiloti, 1998) and fish size (Ferrari and Rossi, 1983-84; Rosecchi and Crivelli, 1992; Scipiloti, 1998).

Besides its direct commercial importance, the sand smelt plays an important role in the estuarine food webs. For example, it is one of the most important links between planktonic, benthic and organisms that regularly, although only temporarily, enter estuarine food webs, such as insects, and carnivorous fish species in the estuary. Sand smelt largely dominated $(49.7 \%)$ in the ichthyofauna composition of the wider area of the Mala Neretva estuary (Sršen, 1995) and seem to efficiently use several properties of this complex ecosystem. However, sand smelt are also the prey of highpriced carnivorous species, such as sea bass, Dicentrarchus labrax. It is noteworthy that the recent construction of levees in the upper parts of the Neretva River estuary, which inadvertently modified the local environment in a way that has led to an increase in the sand smelt population, has been accompanied by a significant increase in the catch of D. labrax (Glamuzina, unpublished data).
These artificial changes of natural ecosystems in the Neretva River estuary significantly affect its biological and economical (mainly fishery) properties, creating new fishery resources and contributing to the welfare of small local communities. In order to quantify the potential benefits and threats of these public works, research into the fish community response and changes was initiated. This paper presents data on the food composition of sand smelt from the Mala Neretva River estuary and relates these to their habitat, seasonality, and population structure.

\section{Study area}

The present study was carried out in the estuary of the Mala Neretva River situated on the southeastern Adriatic coast of Croatia, and the geographic position of the site is: $40^{\circ} 52^{\prime} \mathrm{N} ; 17^{\circ} 40^{\prime} \mathrm{E}$ (Fig. 1). The mouth of the river is blocked with a dam preventing inflow of saltwater into the upper agricultural part of the estuary during dry months. The sampling site was in front of this dam and on the Adriatic Sea side where marine conditions dominate. However, significant outflow of freshwater and pumped polluted freshwater from adjacent agricultural land is constantly added to the site, thus creating an environment of variable salinity. The water mixing leads to daily and seasonal changes in temperature and salinity at the sampling site. Average monthly temperatures varied between $25^{\circ} \mathrm{C}$ in August and $9^{\circ} \mathrm{C}$ in February. Water temperature in winter is affected by the inflow of freshwater, which is colder $\left(7.4^{\circ} \mathrm{C}\right)$ than the sea water $\left(11.4^{\circ} \mathrm{C}\right)$. During the winter period salinity varied between 4 and 38 psu, while during the summer it varied only between 30 and 38.

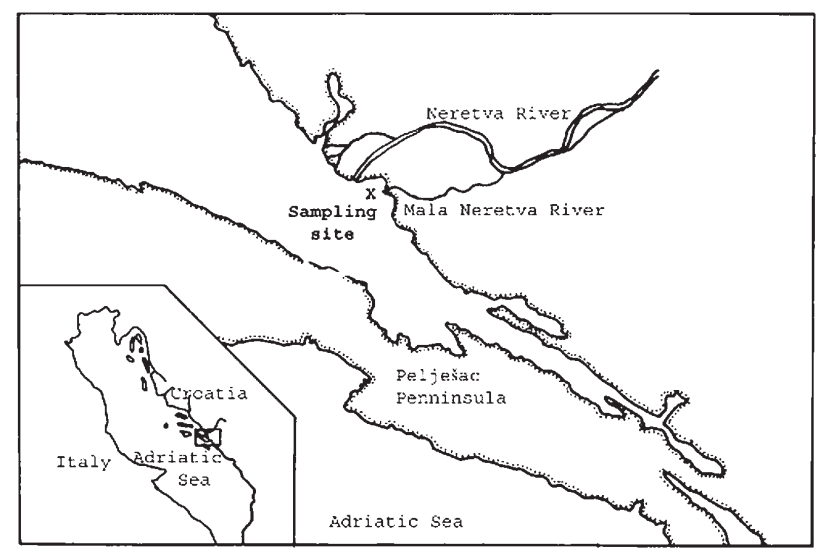

FIG. 1. - Map of the research area 


\section{MATERIALS AND METHODS}

The fish examined $(n=1236)$ were collected monthly from March 2001 to February 2002 at one research station close to the dam at the mouth of Mala Neretva River. The fish samples were collected using a small net (5 $\mathrm{mm}$ mesh size), used locally for sand smelt fishery. It is practically one square metre of net on a metal frame, which is connected by ropes to a main rope and when the fish appear above, the net is lifted out.

Temperature and salinity were measured on-site using portable digital instruments (WTW). The specimens were transported to the laboratory where total (TL) length was measured to the nearest 0.1 $\mathrm{mm}$ using a digital calliper and body weight to the nearest $0.01 \mathrm{~g}$ using an OHAUS digital balance.

After measurement of length and weight, the stomachs were dissected and preserved in $96 \%$ ethanol. Prey composition was determined under a binocular microscope to the lowest possible systematic status.

The frequency of occurrence was determined for each prey category, while the percentage number was determined as the number of individuals, expressed as a percentage of the total in all categories (Hynes, 1950; Pais, 2002). Quantification of stomach contents for abundance calculations was based on the number of identifiable specimens and on "remains", the latter being composed of telsa, jaws, legs, eggs, etc. Therefore, these categories were assigned a value of 1 (Pais, 2002). The index of vacuity was determined (Pais, 2002).

The samples were divided into three length fractions $\left(\mathrm{L}_{\mathrm{t}}\right), \mathrm{L}_{\mathrm{t}} \mathrm{I}(<6 \mathrm{~cm}), \mathrm{L}_{\mathrm{t}} \mathrm{II}(6-7.5 \mathrm{~cm})$, and $\mathrm{L}_{\mathrm{t}}$ III $(>7.5 \mathrm{~cm})$, and three mass fractions $(\mathrm{M}), \mathrm{M} \mathrm{I}(<1 \mathrm{~g})$, M II (1-2 g), and M III (>2 g).

Analysis of Variance (ANOVA) and the SNK multiple range test were used to compare the differences in length and body mass with the total numbers of food categories (see Table 1).

The monthly prey composition of the stomach contents of the samples was analysed with the Principal Components Analysis method in order to define similarities in the presence or absence of certain prey items as well as similarities between the compositions of stomach contents between months. In addition, these similarities were examined using a simple clustering technique based on the Bray-Curtis dissimilarity index and the agglomeration profile was determined with the Thorndike criterion (Aldenderfer and Blashfield, 1984; Ludwig and Reynolds, 1988).

TABLE 1. - Monthly number of counted prey in the stomachs of 1235 (100 monthly) specimens of sand smelt from Mala Neretva River estuary.

\begin{tabular}{|c|c|c|c|c|c|c|c|c|c|c|c|c|c|}
\hline \multicolumn{2}{|c|}{$\begin{array}{l}\text { Depth } \\
\text { (m) }\end{array}$} & $\begin{array}{r}2001 \\
\text { March }\end{array}$ & $\begin{array}{r}\text { April } \\
15.4\end{array}$ & $\begin{array}{l}\text { May } \\
21.4\end{array}$ & $\begin{array}{l}\text { June } \\
25.2\end{array}$ & $\begin{array}{r}\text { July } \\
27.0\end{array}$ & $\begin{array}{r}\text { Aug. } \\
26.9\end{array}$ & $\begin{array}{l}\text { Sep. } \\
23.3\end{array}$ & $\begin{array}{l}\text { Oct. } \\
16.8\end{array}$ & $\begin{array}{r}\text { Nov. } \\
14.5\end{array}$ & $\begin{array}{l}\text { Dec. } \\
12.2\end{array}$ & $\begin{array}{r}2002 \\
\text { Jan. } \\
10.8\end{array}$ & $\begin{array}{r}\text { Feb. } \\
9.0\end{array}$ \\
\hline 1 & & 12.3 & 14.5 & 20.8 & 24.7 & 27.2 & 26.6 & 24.1 & 17.2 & 14.0 & 12.4 & 11.5 & 9.0 \\
\hline 0 & \multirow[t]{2}{*}{ Salinity } & 24.3 & 28.3 & 24.1 & 29.6 & 29.9 & 26.6 & 24.0 & 20.0 & 15.0 & 18.0 & 19.3 & 9.0 \\
\hline 1 & & 35.9 & 33.1 & 31.8 & 32.8 & 31.3 & 27.1 & 25.0 & 24.0 & 19.0 & 21.0 & 22.9 & 15.9 \\
\hline 0 & \multirow[t]{2}{*}{$\mathrm{pH}$} & 6.9 & 7.7 & 6.7 & 6.9 & 8.3 & 7.2 & 6.7 & 7.3 & 7.6 & 8.0 & 7.5 & 7.1 \\
\hline 1 & & 7.2 & 7.5 & 5.8 & 6.9 & 8.3 & 7.4 & 7.2 & 7.5 & 8.0 & 7.7 & 7.5 & 7.0 \\
\hline 0 & \multirow[t]{2}{*}{ D.O. (mg L-1) } & 10.8 & 9.6 & 10.0 & 9.7 & 8.1 & 7.8 & 8.1 & 8.8 & 9.0 & 8.6 & 9.4 & 9.3 \\
\hline (2) & & 11.2 & 9.6 & 10.1 & 9.6 & 8.0 & 8.8 & 8.6 & 8.7 & 9.0 & 10.0 & 9.3 & 10.4 \\
\hline & Cladocera & 0 & 5 & 5 & 0 & 0 & 135 & 5 & 1600 & 350 & 0 & 40 & 5 \\
\hline & Ostracoda & 0 & 0 & 0 & 0 & 0 & 0 & 0 & 0 & 0 & 30 & 5 & 0 \\
\hline \multicolumn{14}{|c|}{ Copepoda } \\
\hline & Calanoida & 5 & 0 & 0 & 0 & 0 & 0 & 0 & 15 & 5 & 5 & 40 & 1450 \\
\hline & Cyclopoida & 280 & 40 & 10 & 0 & 0 & 15 & 0 & 30 & 0 & 0 & 10 & 10 \\
\hline & Harpacticoida & 50 & 130 & 65 & 5 & 5 & 35 & 0 & 45 & 5 & 225 & 625 & 775 \\
\hline & Decapoda Larvae & 25 & 170 & 205 & 5 & 0 & 0 & 5 & 0 & 0 & 5 & 5 & 55 \\
\hline & Decapoda & 0 & 5 & 0 & 5 & 0 & 0 & 0 & 0 & 0 & 0 & 25 & 0 \\
\hline & Mysidacea & 20 & 0 & 0 & 10 & 55 & 60 & 5 & 0 & 0 & 0 & 0 & 0 \\
\hline & Cumacea & 0 & 0 & 0 & 0 & 0 & 5 & 0 & 0 & 0 & 0 & 5 & 25 \\
\hline & Isopoda & 0 & 0 & 0 & 5 & 0 & 0 & 0 & 0 & 0 & 10 & 0 & 10 \\
\hline & Gammaridea & 10 & 60 & 30 & 110 & 35 & 5 & 15 & 10 & 55 & 20 & 50 & 55 \\
\hline & Insecta & 5 & 5 & 0 & 215 & 0 & 0 & 0 & 5 & 0 & 0 & 0 & 0 \\
\hline & Pisces & 0 & 0 & 0 & 0 & 5 & 5 & 0 & 0 & 15 & 0 & 0 & 0 \\
\hline & Gastropoda Larvae & 0 & 0 & 0 & 0 & 0 & 0 & 0 & 0 & 0 & 10 & 10 & 0 \\
\hline & Unidentified Eggs & mass & 0 & 0 & 0 & mass & 0 & 0 & 0 & 0 & mass & 0 & 0 \\
\hline \multicolumn{3}{|c|}{ Reproduction Period } & $\bullet$ & - & $\bullet$ & $\bullet$ & & & & & & & \\
\hline
\end{tabular}




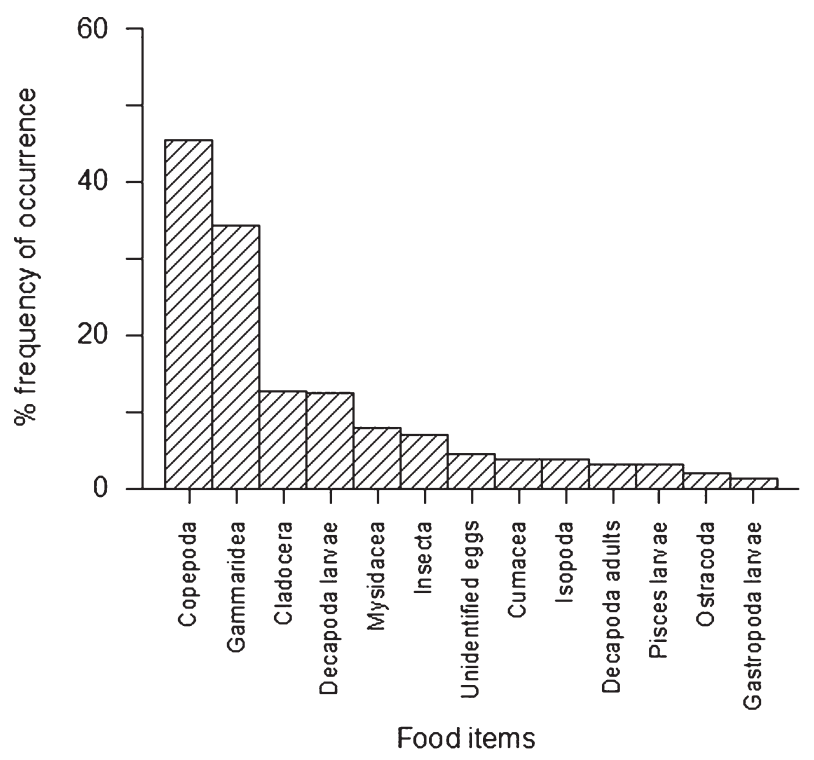

FIG . 2. - Frequency of occurrence (\%) of different prey categories.

\section{RESULTS}

Sixteen different food categories were identified (Table 1). The greatest diversity was recorded in winter, especially in January, when 11 categories were present. The minimum (4) was recorded in September. Marine and estuarine species represented the bulk of the prey, while typically fresh-water species (Daphnia spp. and Cyclops spp.) were found only sporadically. Large aggregations of unidentified eggs-most likely of invertebrates-were found in March, July and December.

Crustaceans were the most common prey and, of these, copepods were the most common (45\%), followed by gammarid amphipods (34\%), cladocerans (13\%), decapod larvae (12\%) and mysids (8\%). Insects represented $7 \%$ (Fig. 2). Five percent of the

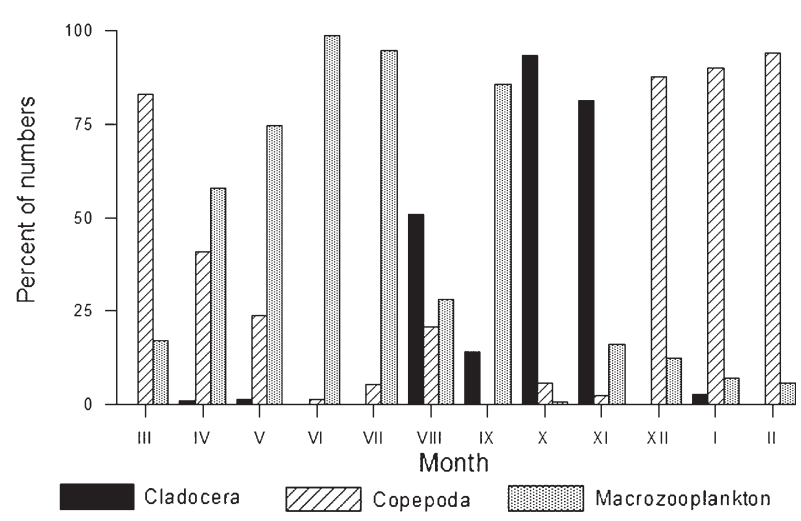

FIG . 3. - Seasonal changes of the most common prey items (percent abundance), with macrozooplankton as the sum of gammarids, decapod larvae, and mysids. material was unidentified. Among the copepods, harpacticoids had the highest frequency of occurrence $(70 \%)$, followed by poecilostomatoids $(32 \%)$, cyclopods $(29 \%)$, and calanoids $(27 \%)$.

The percentage number of prey showed high seasonal variations (Fig. 3). Copepods dominated in autumn and winter, cyclopods-mostly Oithona similis - in March, poecilostomatoids and harpacticoids in January, and calanoids (Paracalanus parvus and Acartia clausi) in February. The maximum relative number of amphipods was recorded in June. Throughout the year, in most cases we recognised Perioculodes longimanus, followed by Guernea coalita and Westwoodilla caecula. Decapod larvae were dominant in April-May, the most common species being Upogebia spp. Mysids were dominant in summer (July and August), especially Mesopodopsis slabberi and Paramysis helleri. Insects (Coleoptera) were dominant in June. The greatest fraction of prey in autumn (October) was cladocera, Penilia avirostris (Table 1).

The mean index of vacuity was high: $36 \% \pm$ $17 \%$. The highest percentage values were in May and July-September; these ranged from $40 \%$ in July to $67 \%$ in September (mean $44 \% \pm 11$ ). In the colder season, the index of vacuity was lower, from $3 \%$ in February to 29\% in December and March (Fig. 4).

Fish length ranged from 4.5 to $11.6 \mathrm{~cm}$ (mean $6.80 \pm 1.17 \mathrm{~cm}$ ). Significantly higher numbers of cladocerans and copepods were found in the stomachs of the smallest fish. Decapoda larvae, mysids, and egg aggregations were prominently abundant in the stomach of the largest fish (Table 2).

Comparison of body mass with the length of fish with food in their stomachs showed a positive corre-

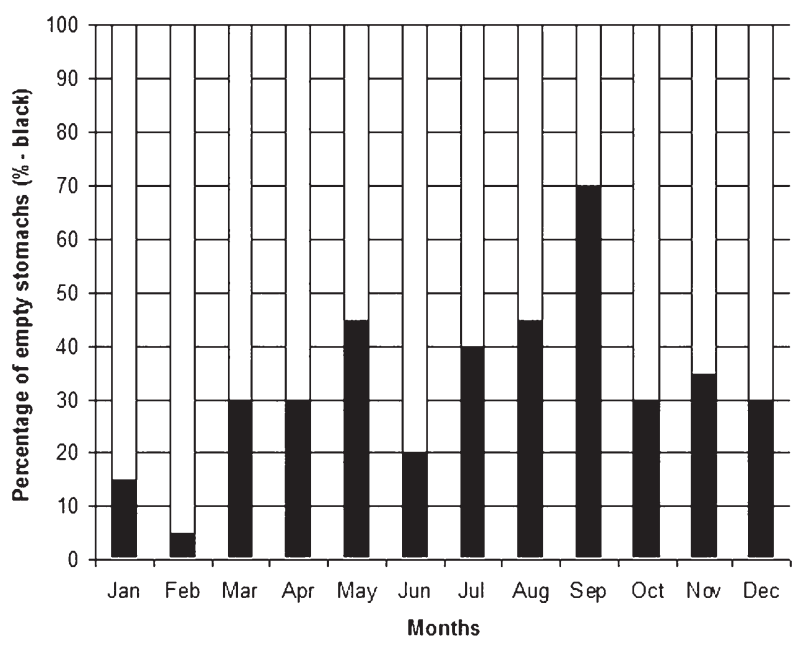

FIG . 4. - Percentage of empty stomachs (black) in monthly samples. 
TABLE 2. - Results of Analysis of Variance (ANOVA) and SNK multiple range test between the three different length and body mass groups, and number of prey categories found in all fishes (Differences were considered statistically significant at $\mathrm{P}<0.05$; ns=not significant).

\begin{tabular}{|c|c|c|c|c|c|c|}
\hline & $\begin{array}{l}\text { Length } \\
\text { LtI }\end{array}$ & Lt II & Lt III & $\begin{array}{l}\text { Mass } \\
\text { M I }\end{array}$ & M II & M III \\
\hline Taxon & $\mathrm{n}=207$ & $\mathrm{n}=334$ & $\mathrm{n}=227$ & $\mathrm{n}=251$ & $\mathrm{n}=221$ & $\mathrm{n}=296$ \\
\hline CLADOCERA & 0.001 & ns & $\mathrm{ns}$ & 0.05 & ns & ns \\
\hline COPEPODA & 0.001 & $\mathrm{~ns}$ & $\mathrm{~ns}$ & $<0.001$ & ns & $\mathrm{ns}$ \\
\hline DECAPODA LARVAE & ns & ns & 0.05 & ns & ns & ns \\
\hline MYSIDACEA & $\mathrm{ns}$ & ns & 0.02 & ns & $\mathrm{ns}$ & 0.05 \\
\hline Unidentified eggs & ns & ns & $<0.01$ & ns & ns & 0.05 \\
\hline
\end{tabular}

lation: $\mathrm{n}=755, \mathrm{r}=91, P<0.001$ (Pearson coefficient of correlation). Body mass ranged from 0.39 to $11.93 \mathrm{~g}$ (mean: $1.90 \pm 1.33 \mathrm{~g}$ ). There was a minor significant difference between body mass size classes and the number of prey (Table 2).

Principal Components Analysis based on the prey items compositions revealed significant eigenvalues for 4 axes (values $>1$ ). Prey composition was different for June and December only, while the rest of the months are clustered within the first axis, which explains almost $50 \%$ of the total variability (Table 3). Bray-Curtis similarity clustering based also on the prey composition showed the highest similarity between 3 of the copepod groups (Harpacticoida, Poecilostomatida and Calanoida) and between Gastropoda and Ostracoda. The rest of the taxa identified cluster together at similarity levels of less than $50 \%$, indicating that there are no particular patterns in the prey composition (Fig. 5b).

Clustering based on months showed that the highest similarity occurred between April and May,

TABLE 3. - Principal Components Analysis results of sandsmelt, Atherina boyeri from Mala Neretva River estuary.

\begin{tabular}{|c|c|c|c|c|}
\hline \multicolumn{5}{|c|}{ PCA axes (value $>1$ ) } \\
\hline Eigenvalues & 1 & 2 & 3 & 4 \\
\hline Value & 5.7924 & 1.9396 & 1.3040 & 1.0350 \\
\hline$\%$ of variability & 48.27 & 16.16 & 10.87 & 8.62 \\
\hline Cumulative $\%$ & 48.27 & 64.43 & 75.30 & 83.93 \\
\hline \multicolumn{5}{|c|}{ Correlations between initial variables and principal factors : } \\
\hline facto & or 1 fa & or 2 fa & or 3 fo & or 4 \\
\hline Jan & $0.6337 *$ & -0.6557 & -0.0225 & 0.0130 \\
\hline Feb & $0.6352 *$ & -0.5235 & -0.2552 & 0.0119 \\
\hline Mar & $0.7409 *$ & 0.2980 & -0.2608 & -0.2830 \\
\hline Apr & $0.7841 *$ & 0.2004 & -0.3238 & -0.3716 \\
\hline May & $0.9075 *$ & 0.0393 & -0.1913 & -0.2112 \\
\hline Jun & 0.4830 & $0.6702 *$ & -0.3484 & 0.2158 \\
\hline Jul & $0.7112 *$ & 0.3742 & 0.2491 & 0.4529 \\
\hline Aug & $0.6326 *$ & 0.0755 & $0.6641 *$ & -0.0805 \\
\hline Sep & $0.7703 *$ & 0.3513 & 0.0874 & 0.1890 \\
\hline Oct & $0.7553 *$ & -0.3925 & 0.1992 & -0.2840 \\
\hline Nov & $0.7365^{*}$ & -0.1285 & 0.4271 & 0.1808 \\
\hline Dec & 0.3930 & -0.4649 & -0.4181 & $0.6039 *$ \\
\hline
\end{tabular}

(*) indicates characteristic factor (factor $>0.5$ ) and between December and January (Fig. 5a). The agglomeration profile, according to Thorndike's criterion, showed two major clusters of months. Clustering based on prey items showed 2 clusters of months (with varying inter-group similarities; Fig. $5 \mathrm{a}, \mathrm{b})$. The first group spans from February to March; the second, from June to July. The data (Table 1) show clearly that during the first period (December-May) prey are more abundant and their
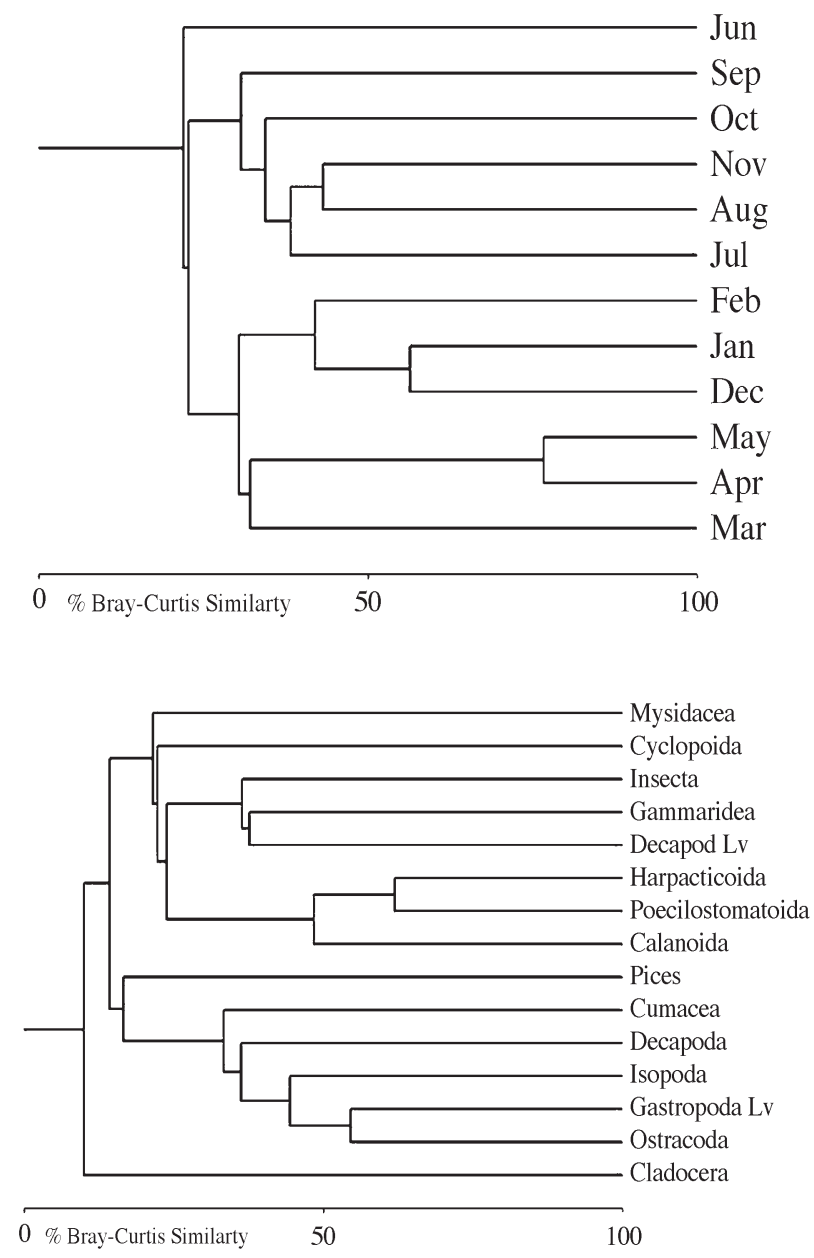

FIG . 5. - Bray-Curtis clustering scheme based on the similarities of: a) monthly samples and b) the prey items and for the sand smelt, Atherina boyeri in Mala Neretva River estuary. 
diversity is higher. The second period is characterised by low numbers of prey (except in October, when a very high number of cladocerans appeared) and low prey diversity.

\section{DISCUSSION}

Crustaceans were the most common prey of sand smelt in the Mala Neretva River estuary. Copepods were the most common crustaceans (45\%). Of these, harpacticoids were found throughout the year, with especially high numbers in winter and spring. Cladocerans were the most numerous in autumn. Macrozooplanktonic were very frequent prey. Gammarid amphipods were the second most common prey and were present throughout the year. Mysids and cumaceans were also important. Along with decapoda larvae, they were the most important prey in spring and summer. These three groups are numerous in the nocturnal zooplankton of Mali Ston Bay (Lučić, 1986), and the mysid Mesopodopsis slabberi was extremely abundant (10-15 ind. $\mathrm{m}^{-3}$ ) during the day at the mouth of the Neretva from May to July (Lučić, unpublished data). Of other prey, insects and as yet unidentified eggs were prominent. Typical elements of the benthos, such as adult decapods, were rare.

According to optimal foraging theory, the probability of prey capture is a function of a prey's density, size, total visibility, and motion (Lazzaro, 1987). Although the prey variability found in sand smelt stomachs in the study area is in accordance with previous studies (Kiener and Spillman, 1969; Trabelsi et al., 1994), its seasonal composition is different. For example, sand smelt from Suez Channel fed on copepods mostly in summer (Fouda, 1995), which contrasts with our results. The same discrepancy was reported by Vizzini and Mazzola (2002), but in our case mysids and isopods dominated in winter and spring. Our results point to opportunism as the dominant feeding strategy, as well as a clear preference for zooplankton, as found by others (Castel et al., 1977; Gon and Ben-Tuvia, 1983). When zooplankton is scarce, however, sand smelt shift exclusively to benthic prey (Trabelsi et al., 1994), and in our case when benthic prey was available the sand smelt used it.

The diversity of prey in the stomachs of sand smelt varied seasonally, with greater diversity in winter. This is consistent with the local composition of zooplankton, which was also more diverse in winter (Lučić, 1986; Lučić and Onofri, 1990; Lučić and Kršinić, 1998).

The relative abundance of prey does not necessarily correspond to the distribution of their biomass. Copepods, for example, have a higher specific weight than cladocerans (Fonda-Umani and Specchi, 1979), and that of macrozooplankton is higher still. Further, the high nutritional value of copepods (Stottrup, 2000) and mysids (Mauchline, 1980) is well established. Lučić (1985) estimated that mysids, decapoda larvae and amphipods contributed significantly to the total production of net zooplankton in the Mali Ston Bay, and it was this group that dominated the gut contents of sand smelt during and after the spawning period.

Significantly higher numbers of cladocerans and copepods were found in the guts of the smallest fish, while decapoda larvae, mysids, and egg aggregations predominated in the stomachs of the largest. The mid-length group of fish preyed on all of these items. These results reflect the importance of sizeselection in sand smelt nutrition (Table 2). This also points to the importance of all age classes of sand smelt as major consumers of a wide spectrum of planktonic prey, including prey diversity and dimensions, in the estuaries. The well-structured sand smelt population preyed on virtually all kinds of suitable planktonic food in the estuaries, providing higher members of food webs, mainly different fish species, with an abundant and rich food source.

The great number of empty stomachs was found during spring spawning and in summer, especially in September. On the other hand, the smallest number of empty stomachs was found during winter. A high percentage of empty stomachs in summer was also found in sand smelt from Bardawil Lagoon, Israel (Gon and Ben-Tuvia, 1983). The overall vacuity index is also very low (36\%), while the percentage of empty stomachs is rather high. This suggests several important conclusions. It seems that the food composition of the plankton in the study area may not be fully appropriate, either in terms of quality and quantity, at least during the summer season. Thus, the species probably appears and stays in the area for reasons other than food. The study area is part of its natural course of migration between marine and freshwater, and this course is interrupted by the dam, which only periodically opens the gates (Bartulović, 2003). Hence, we may have dealt with part of population waiting for the free road to freshwater, at least during some parts of the year. This indicates that the study area may be a transition- 
waiting zone between marine and freshwater ecosystems. The other explanation for low stomach fullness throughout the year could be constant and unpredictable abrupt changes in salinity and temperature that affect fish behaviour and feeding (Bartulović et al., 2004). However, these changes were extreme in winter when we observed the lowest percentage of empty stomachs. Hence, even if this has some influence, it is not a major reason. Finally, it is difficult to name one reason for the high level of empty stomachs, but the instability of the ecosystem in general may lead to lower prey availability and lower feeding frequency of sand smelt in the Mala Neretva River estuary.

The recent propagation of sand smelt in the Neretva River estuary associated with riverbanks public works has created new food webs and new potential fishery resources in the area. This event provides us with a potentially useful case study in promoting new habitat development as a benefit, and not only an ecological disaster. The description of biological and economic values of new food webs in the estuary will be investigated in future, with the results of this paper forming the basis.

\section{REFERENCES}

Aldenderfer, M.S., and R.K. Blashfield. - 1984. Cluster analysis, (ed. M.S. Lewis-Beck), Sage University Papers, Series No, 07044, Quantitative Applications in the Social Sciences, Sage Publications Inc., p. 87

Bartulović, V., Glamuzina, B., Conides, A., Dulčić, J., Lučić, D., Njire, J. and V. Kožul. -2004. Age, growth, mortality and sex ratio of sand smelt, Atherina boyeri Risso, 1810 (Pisces, Atherinidae) in the estuary of the Mala Neretva River (middleeastern Adriatic, Croatia). J. Appl. Ichthyol, 20: 427-430.

Bartulović, V. - 2003. Morphometry and population dynamics of sand smelt, Atherina boyeri Risso, 1810 (Pisces) in the estuary of Mala Neretva River. Master Thesis, University of Zagreb, Croatia. p. 99 (in Croatian)

Castel, J., Cassifour, O. and P.J. Labourg. - 1977. Croissance et modifications du regime alimentaire d'un téleostéen mugiliforme: Atherina boyeri Risso, 1810 dans les étangs saumâtres du bassin d' Arcachon. Vie Milieu, 27: 385-410.

Economidis, P.S., Dimitriou, E., Pagoni, R., Michaloudi, E., and L. Natsis. -2000. Introduced and translocated fish species in the inland waters of Greece. Fish. Man. Ecol., 7: 239-250.

Ferrari, I. and R. Rossi. - 1983-1984. Feeding habits of Atherina boyeri Risso in a lagoon of the Po river delta. Nova thallasia, 6: 275-280.
Fonda Umani, S. and M. Specchi. - 1979. Dati quantativi sullo zooplancton raccolto presso le due bocche principali della laguna di Grado (Alto Adriatico), Atti Soc. Toscana Sci. nat. Mem., Ser. B(Suppl.): 89-93.

Fouda, M.M. - 1995. Life history strategies of four small-size fishes in the Suez Canal, Egypt. J. Fish. Biol., 46: 687-702.

Gon, O. and A. Ben-Tuvia. - 1983. The biology of Boyer's sand smelt, Atherina boyeri Risso in the Bardawil Lagoon on the Mediterranean coast of Sinai. J. Fish. Biol., 22: 537-547.

Hynes, H.B.N. - 1950. The food of fresh-water sticklebacks (Gasterosteus aculeatus and Pygosteus pungitus), with a review of methods used in studies of the food of fishes. J. Animal Ecol., 19: 36-58.

Kiener, A. and C.J. Spillmann. - 1969. Contribution a l'etude systematique et ecologique des atherines des cotes francaises. Mem. Mus. natn. Hist. nat., Paris, Ser. A, Zool. 60: 33- 74.

Lazzaro, X. - 1987. A review of planktivorous fishes: their evolution, feeding behaviours, selectivities and impact. Hydrobiology, 146: 97-167.

Lučić, D. - 1985. Day-night variations in mesozooplankton and macrozooplankton in the Mali Ston Bay. MSc thesis, University of Zagreb, 97 pp. (In Croatian with English summaries)

Lučić, D. - 1986. Mysidacea, Cumacea and Amphipoda in the Mali Ston Bay (Southern Adriatic). Studia Marina, 17-18: 179-198. (In Croatian with English summary)

Lučić, D. and V. Onofri, V. - 1990. Seasonal variations of neritic mesozooplankton in Mali Ston Bay (Southern Adriatric). Acta Adriat., 31: 117-137.

Lučić, D. and F. Kršinić. - 1998. Annual variability of mesozooplankton assemblages in Mali Ston Bay (Southern Adriatic). Period. Biolog., 100: 43-52.

Ludwig, J.A. and J.F. Reynolds. - 1988. Statistical ecology. A primer on methods and computing. John Wiley \& Sons, New York, pp. 337

Mauchline, J. - 1980. The biology of mysids and euphausids. Advanced Marine Biology, 18: 1-369.

Pais, C. -2002 . Diet of a deep-sea fish, Hoplostethus mediterraneus, from the south coast of Portugal. J. Mar. Biol. Ass. UK, 82, 351-352.

Quignard, J.P. and A. Pras. - 1986. Atherinidae. In: P.J. Whitehead, M.L. Bauchot, J.C. Hureau, J. Nielsen and E. Tortonese (eds.), Fishes of the North-eastern Atlantic and the Mediterranean, pp. 1207-1210. Paris: UNESCO.

Rossechi, E. and A.J. Crivelli. - 1992. Study of a sand smelt (Atherina boyeri Risso, 1810) population reproducing in fresh water. Ecol. Freshwater Fish, 1(2): 77-85.

Scipiloti, D. - 1998. Fish community in the Stagnone di Marsala: distribution and resource partitioning as a function of different habitat complexity degrees. $\mathrm{PhD}$ dissertation, University of Messina, Italy.

Sršen, V. - 1995. Ichthyofauna of the Neretva River estuary. BSc thesis. Faculty of Science. University of Zagreb. 50 pp. (In Croatian)

Stottrup, J.G. - 2000. The elusive copepods: their production and suitability in marine aquaculture. Aquac. Res., 31: 703-711.

Trabelsi, M., F. Kartas and J.P. Quignard. - 1994. Comparaison du régime alimentaire d'une population marine et d'une population lagunaire d' Atherina boyeri des côtes tunisiennes. Vie Milieu, 44: 117-123.

Vizzini, S. and A. Mazzola. - 2002. Stable carbon and nitrogen ratios in the sand smelt from a Mediterranean coastal area: feeding habits and effect of season and size. J. Fish. Biol., 60: 14981510.

Scient. ed.: G. Pequeño 
